\title{
Yükseköğretim Öğrencilerinin 'Uzaktan Eğitim' Kavramına İlişkin Metaforik Algıları: Kilis 7 Aralık Üniversitesi İslami İlimler Fakültesi Örneği
}

\author{
Ali Güngör \\ Dr. Öğr. Üyesi, Kilis 7 Aralık Üniversitesi (ROR ID: 048b6qs33) \\ İslami İlimler Fakültesi, Din Eğitimi Anabilim Dalı \\ Assist. Prof. Dr., Kilis 7 Aralk University, Faculty of Islamic Sciences \\ Department of Religious \\ Education \\ Kilis/Turkey \\ aligungor@kilis.edu.tr \\ ORCID: 0000-0002-7655-4021
}

\section{An Analysis of the Metaphoric Perceptions of Higher Education Students Regarding the Concept of 'Distance Education': An Example from Kilis 7 Arallk University, Faculty of Islamic Sciences}

\begin{abstract}
Since the beginning of the COVID-19 pandemic, higher education institutions in Turkey have started to give the courses through distance education in order to prevent the spread of the virus. Unlike classical distance education, it is absolutely necessary to know the characteristics of these unprecedented distance education practices, for which students, teachers, and educational institutions were caught unprepared. Based on such a need, this study aimed to determine the metaphorical perceptions of higher education students regarding the concept of "distance education" and carried out in line with the qualitative phenomenological research design method.

The study consisted of 197 female and male students who attended different classes at Kilis 7 Aralık University, Faculty of Islamic Sciences in the 2020-2021 academic year and participated in distance education from different settlements such as villages, districts, and towns. The relevant data were collected using a semi-structured form in which the students who continued their compulsory distance education due to the COVID-19 pandemic were asked to write a metaphor and their justification for generating such a metaphor by completing the gaps in the statement "Distance education is like ... because ...".
\end{abstract}

Veri toplamak için Kilis 7 Aralık Üniversitesi Etik Kurulu'ndan (23/03/2021 tarih, 2021/08 sayılı karar) izin alınmıştır. Ethical permission approval was obtained from Kilis 7 Aralık University Scientific Research and Publication Ethics Committee with the decision dated 23/03/2021 and numbered 2021/08

İntihal Taraması/Plagiarism Detection: Bu makale intihal taramasından geçirildi/This paper was checked for plagiarism Etik Beyan/Ethical Statement: Bu çalışmanın hazırlanma sürecinde bilimsel ve etik ilkelere uyulduğu ve yararlanılan tüm çalışmaların kaynakçada belirtildiği beyan olunur/It is declared that scientific and ethical principles have been followed while carrying out and writing this study and that all the sources used have been properly cited (Ali Güngör). Geliş/Received: 31 Mayıs/May 2021 | Kabul/Accepted: 25 Ağustos/August 2021 | Yayın/Published: 20 Eylül/September 2021 Atıf/Cite as: Ali Güngör, "Yükseköğretim Öğrencilerinin ‘Uzaktan Eğitim’ Kavramına İlişkin Metaforik Algıları: Kilis 7 Aralık Üniversitesi İslami İlimler Fakültesi Örneği = An Analysis of the Metaphoric Perceptions of Higher Education Students Regarding the Concept of 'Distance Education': An Example from Kilis 7 Aralık University, Faculty of Islamic Sciences", Eskiyeni 45 (Eylül/September 2021), 693-717. https://doi.org/10.37697/eskiyeni.945841

CC BY-NC 4.0 | This paper is licensed under a Creative Commons Attribution-NonCommercial License 
As a result of the analyses, it was determined that 167 different metaphors were produced by 197 participants. The metaphors were grouped under 11 themes, 9 of which belonged to the negative category and 2 to the positive category. When the metaphors were examined, it was concluded that the students' perceptions of distance education were mostly expressed negatively. Those who expressed negative opinions about distance education formed their metaphors in line with the themes of being "deceptive" and "artificial", and in such a way to show metaphors in which distance education intends to stand in for face-to-face learning, but does not have the characteristics of it, no matter how much it tries to resemble it.

The metaphors in the positive category consist of two themes mentioned as follows: Under the theme of being "advantageous", students stated that distance education provided them with both the comfort of being at home and the advantage of continuing their education. Within the theme of being "necessary", distance education was expressed as a necessity to replace face-to-face learning and prevent interruptions in education during the pandemic.

Although the metaphors given by the students about distance education were mostly negative, it was discovered that none of the students at the Faculty of Islamic Sciences, where the participating students were studying, preferred to defer enrolment during the pandemic. All these data can be evaluated in the sense that some of the drawbacks that emerged at the beginning of the pandemic have been overcome in time and that students have turned to adapt to distance learning despite the above-mentioned negativities.

\section{Keywords}

Religious Education, Distance Education, Metaphors, Higher Education, Faculty of Islamic Sciences Students

\section{Yükseköğretim Öğrencilerinin 'Uzaktan Eğitim' Kavramına İlişkin Metaforik Algıları: Kilis 7 Aralık Üniversitesi İslami İlimler Fakültesi Örneği}

\section{Öz}

Covid-19 pandemisinden sonra virüsün yayılmasını önlemek amacıyla ülkemizdeki yükseköğretim kurumları derslerini uzaktan eğitim yoluyla vermeye başlamıştır. Klasik uzaktan eğitimden farklı olarak, öğrenci, öğretici ve öğretim kurumlarının hazırlıksız yakalandığı bu olağan dışı uzaktan eğitim uygulamalarının niteliklerinin bilinmesine ihtiyaç vardır. Bu ihtiyaçtan hareketle yükseköğretim öğrencilerinin "uzaktan eğitim" kavramına ilişkin metaforik algılarını belirlemeyi amaçlayan bu çalışma, nitel araştırma yöntemlerinden olgubilim (fenomenoloji) deseninde tasarlanmıştır.

Araştırmanın katılımcılarını, 2020-2021 öğretim yılında Kilis 7 Aralık Üniversitesi İslami İlimler Fakültesinin değişik sınıflarında öğrenim gören, uzaktan eğitime köy, ilçe ve il gibi farklı yerleşim birimlerinden katılan 197 kız ve erkek öğrenci oluşturmaktadır. Veriler, Covid 19 pandemisinden dolayı zorunlu olarak uzaktan eğitime devam eden öğrencilere "Uzaktan eğitim...... gibidir. Çünkü........" ifadesindeki boşluklara uygun bir metafor ve metaforun gerekçesini yazmalarının istendiği yarı yapılandırılmış form kullanılarak toplanmıştır.

Analizler sonucunda katılımcı 197 öğrenci tarafından 167 farklı metafor üretildiği tespit edilmiştir. Üretilen metaforlar olumsuz temasına ait 9 ve olumlu temasina ait 2 alt tema olmak üzere toplam 11 alt tema altında toplanmıștır. Araştırmada üretilen metaforlar incelendiğinde öğrencilerin uzaktan eğitime yönelik algılarının çoğunlukla olumsuz olarak ifade edildiği sonucuna ulaşılmıştır. Uzaktan eğitimle ilgili olumsuz görüş belirten öğrenciler, en çok metafor ürettikleri "aldatıcı" ve "yapay" temasında, uzaktan eğitimin yüzyüze eğitimin yerini tutmaya çalışan fakat ne kadar ona benzemeye çalışsa da onun özelliklerine sahip olamadığını gösteren metaforlara yer vermişlerdir. 
Olumlu temasında olan metaforlar ise iki alt temadan oluşmaktadır. “Avantaj” temasında öğrenciler uzaktan eğitimin kendilerine hem evde olmanın konforunu hem de öğrenime devam etmenin avantajını sağladı̆̆ını ifade etmişlerdir. "Gerekli” temasında ise, uzaktan eğitim, pandemi sürecinde yüzyüze eğitimin yerini doldurması ve eğitimde kesinti yaşanmaması için bir gereklilik olarak dile getirilmiştir.

Öğrencilerin uzaktan eğitimle ilgili ürettikleri metaforlar çoğunlukla olumsuz olmasına rağmen, katılımcı öğrencilerin eğitim aldığı İslami İlimler Fakültesinde hiçbir öğrencinin pandemi sürecinde kayıt dondurma yolunu tercih etmedikleri bilgisi alınmıștır. Bütün bu veriler pandemi sürecinin başında ortaya çıkan bazı olumsuzlukların zamanla aşıldığı ve öğrencilerin yukarıda sayılan olumsuzluklara rağmen uzaktan eğitime uyum sağlamaya başladıkları anlaminda değerlendirilebilir.

\section{Anahtar Kelimeler}

Din Eğitimi, Uzaktan Eğitim, Metafor, Yükseköğretim, İslami İlimler Fakültesi Öğrencileri

\section{Giriş}

Metafor (eğretileme), "nitelikleri ya da anlamı belli bir gerçeklik düzeyinden bir başkasına taşımak, bilineni bilinmeyene aktarmak suretiyle gerçekleşen; bir benzerliğe işaret etmekten başlayıp bir çağrışımlar yumağı meydana getirmeye kadar genişleyebilen bir söz sanatı" olarak tanımlanmaktadır (Cevizci, 1999, 286). Bir kişinin bir kavramı ya da olguyu algıladığı şekilde, benzetmeler kullanarak ifade etmesi de metafor olarak tanımlanmaktadır (Aydın, 2013).

Aristo, "sıradan sözcüklerin bildiğimiz şeyleri ilettiğini, yeni şeylerin ise en iyi metafordan elde edilebileceğini” ifade etmiştir (Aristoteles, 1995, 184). "Metaforik düşünce iki farklı şey arasında, benzerlikleri dikkate alarak bağlantılar kurabilme yeteneğidir... Öğretim amaçlı metaforlar bir kavramsal alanı başka bir kavramsal alan ile bağlantılamak için kullanılabilirler" (Arslan - Bayrakc1, 2006, 104). Metaforlar, tanımlanmak istenen olgunun tamamını değil bir yönünü temsil etmektedirler ve dolayısıyla olgunun farklı yönlerine vurgu yapacak çok sayıda metafora ihtiyaç vardir (Saban, 2008).

Son yıllarda metaforlar kullanılarak çeşitli olgulara ilişkin algıların belirlenmesine yönelik araştırmalar yaygınlaşmaya başlamıştır. Eğitim bilimleri alanında, öğretmen ve öğrencilerin, çeşitli kavramlara yönelik algıların metaforlar yoluyla incelendiği çok sayıda çalışma yapıldı̆̆ı görülmektedir (Gürbüzoğlu Yalmancı - Aydın, 2014; Gencer, 2020; Turan vd., 2016). Din eğitimi literatürü incelendiğinde ise, din (Ylld1rım - Gazel, 2018), çevre (Demir, 2017), Din Kültürü ve Ahlak Bilgisi dersi ve öğretmeni (Taş, 2019), İmam Hatip Liseleri, Meslek dersleri öğretmeni ve idarecileri (Karateke, 2019), cami ve din görevlisi (Özdemir - Karateke, 2018), kampüste ilahiyat okuma (Meydan, 2020) gibi kavramların ele alındığı, katılımcıların bu kavramlara yönelik geliştirdikleri metaforlar ve tanımlamaların tespit edilmeye çalışıldığı görülmektedir.

2020 yılında Covid-19 salgınının yayılmasını önlemek için okullarda yüz yüze eğitime ara verilmiş ve eğitim kurumlarında çoğunlukla uzaktan eğitime geçilmiştir. Dolayısıyla uzaktan eğitim konusunda yapılan araştırmalarda da bir artış meydana 
gelmiştir. Hatta bir bilimsel dergi sadece uzaktan eğitim konusuna yönelik araştırmaları içeren sayı çıkarmıştır. ${ }^{1}$ Pandemi döneminde yapılan araştırmalardan bir kısmı da öğrenci ve öğreticilerin uzaktan eğitim konusundaki metaforik algıları ile ilgilidir.

Uzaktan eğitim; "öğretici ile öğrencilerin aynı fiziksel ortamı paylaşmaksızın hatta bazı çalışmalarda aynı zaman dilimini de paylaşmadıkları, teknolojik araçların işe koşulması yoluyla eğitim-öğretim-öğrenim çalışmalarının belli bir program çerçevesinde sürdürülmesidir." (Gülnar, 2008, 262) diye tanımlanmaktadır. İletişim teknolojilerinin hızla gelişmesi, eğitim sisteminin yapısını, öğrenme ve öğretme faaliyetlerini etkilemekte ve bu etkiyle "küresel eğitime" doğru bir gidişten söz edilmektedir (Issman, 2008). Öğretici ve öğrencilerin birbirlerinden uzakta ve farklı mekânlarda olduğu açık ve uzaktan eğitim çalışmaları küresel eğitimin yaygınlaşmasında büyük rol oynamaktadır.

İlk uygulaması 1728'de, Bostonian Caleb Phillips isimli öğretmenin okul bölgesi dışında yaşayan öğrencilerine her hafta öğrenme programını posta ile göndererek derslere katılabilecekleri önerisiyle (Cabı - Ersoy, 2017) başlayan uzaktan eğitim, tek yönlü ve çift yönlü radyo-televizyon uygulamaları ile devam etmiştir. Günümüzde gelişen iletişim teknolojileri sayesinde niteliği daha da artırılmış olarak, telekonferans ve internet modelleri biçiminde yapılmaktadır (İşman, 2008).

Diğer ülkelerin eğitim sistemlerinde var olan fiziki yapı ve araç gereç yetersizliği, kaliteli öğretmen eksikliği ve ailelerin eğitime ilgisizliği gibi sorunlar Türk eğitim sisteminde de bulunmaktadır. Bu eğitim sorunlarının çözümünde sanal ortamlarda yürütülen uzaktan eğitim uygulamaları çeşitli firsatlar sunmaktadır (İşman, 2008). Özellikle tüm dünyada yayılan Covid-19 pandemisi sonrası uzaktan eğitim uygulamaları öğrenci ve öğretmenler için eğitimde öğrenme kayıplarının önlenmesi ve eğitimin sürdürülmesinde çok önemli bir görev üstlenmiştir.

Uzaktan eğitim sayesinde öğrenciler hem ülkemizde hem de yabancı ülkelerde önlisans, lisans ve lisansüstü eğitim almak firsatını elde edebilmektedirler. Uzaktan eğitim yoluyla eğitim veren üniversitelerden en çok bilinenler, İstanbul, Sakarya, Atatürk, Ankara ve İnönü üniversiteleridir. İlahiyat alanında da bilgisayar teknolojilerinden yararlanılarak uzaktan ve açıköğretim yoluyla önlisans ve lisans tamamlama eğitimleri verilmektedir. Bu eğitimler daha önceden hazırlanan içerikler, ders sunumları, ders videoları, deneme sınavları ve yüz yüze sınavlar şeklinde planlı şekilde yapilmaktadir.

Son dönemde dünya ile birlikte ülkemizde de yayılan Covit-19 (korona) virüsünden sonra alınan kararla ${ }^{2}$ bütün üniversitelerde eğitime üç hafta ara verilmiştir. Bu üç haftalık aranın ardından, üniversiteler yeniden açllamamış ve bütün üniversiteler eğitimlerini uzaktan eğitimle devam ettirmek zorunda kalmışlardır.

Devlet okullarına kayıtll, 4.116.698'i açıöğretim ve 79.523'ü uzaktan eğitim olmak üzere toplam 4.196.221 yükseköğretim öğrencisi eğitimlerini okula gelmeden

2 https://covid19.yok.gov.tr/Documents/alinan-kararlar/02-coronavirus-bilgilendirme-notu-1.pdf Erişim: 06/04/2021. 
sürdürmektedirler. ${ }^{3}$ Fakat pandemi süreciyle birlikte ilk defa eğitim sisteminin tamamında uzaktan eğitim yapmak zorunda kalınmıştır. Bu acil durumda çevrim içi dersler, sanal sınıflar gibi yollarla öğrenmenin sürekliliği sağlanmaya çalışılmaktadır. Ancak alt yapı eksikliği, internete erişim ve teknolojik imkânlardaki yetersizlikler öğrencilerin uzaktan eğitime katılması konusunda bazı sorunlar oluşturmaktadır. Bu olumsuz şartlarda yürütülen uzaktan öğrenme uygulamaları, planlı programlı ve teknik altyapısı oluşturulmuş klasik uzaktan eğitim olarak değil, sadece pandemi dönemine mahsus, öğrencilerin öğrenme kayıplarını önlemek amacıyla alınan bir tedbir olarak görülmektedir (Karip, 2020). Bundan dolayı, salgın ve kriz sürecinde gerçekleştirilen uzaktan öğretim faaliyetleri, geleneksel uzaktan öğretim sürecinden ayrı tutularak “acil uzaktan öğretim” olarak da adlandırılmıştır (Yavuz vd., 2020).

Uzaktan eğitim ve açıköğretim altyapı ve tecrübesi olan üniversiteler yüz yüze eğitimden uzaktan eğitime geçişlerinde diğer üniversitelere göre teknik yönden daha az sorun yaşamışlar hatta bu üniversitelerin YÖK koordinesinde, altyapısı uygun olmayan üniversitelere teknik destek sağlamaları kararlaştırılmıştır. ${ }^{4}$ Mesela Sakarya Üniversitesi, aralarında Kilis 7 Aralık Üniversitesinin de bulunduğu 16 üniversiteyi eğitim altyapılarından yararlandırmıştır. Bu araştırma katılımcılarının öğrenim gördüğü Kilis 7 Aralık Üniversitesi, 2020 yılı Mart ayında eğitime verilen üç haftalık arada, uzaktan eğitimin nasıl olabileceği ile çalışmalarını hızlı bir şekilde tamamlayarak eğitimin Zoom, Teams, Meet, Edmodo vb. uzaktan eğitim yapilabilecek programlarla yürütülmesi kararını almıştır. 2019-2020 Bahar döneminin son iki ayı bu şekilde tamamlanmıştır. Ancak 2020-2021 öğretim yılında Covid-19 pandemisinin devam etmesi, altyapısı uygun olmayan diğer kurumlar gibi bu kurumu da bir çözüm arayışına itmiştir. Bu arayış Sakarya Üniversitesi ile yapılan anlaşmalar neticesinde eğitimlerin Sakarya Üniversitesinin Uzep programı kullanılarak devam ettirilmesiyle son bulmuştur.

Yükseköğretim kurumlarında uzaktan eğitim uygulamasına geçilmesinden sonra araştırmacıların bu konuya yöneldikleri, uzaktan eğitim konusunda eğiticilerin ve öğrencilerin görüşlerini belirlemeye yönelik çalışmalar yaptıkları görülmektedir. Pandemi öncesi bazı ortak zorunlu derslerin dışında, uzaktan eğitim konusunda tecrübesi olmayan İlahiyat/İslami İlimler Fakültesi öğrencilerinin, zorunlu olarak geçilen uzaktan eğitim uygulamasının niteliği ve bu konuda yaşadıkları sorunların neler olduğu ile ilgili görüşlerinin bilinmesine ihtiyaç vardır. Dolayısıyla İlahiyat Fakültesi öğrencilerinin uzaktan eğitimle ilgili görüşlerini ele alan çalışmalar da yapılmıştır. Pandemi döneminde, İlahiyat alanındaki yükseköğretim öğrencilerinin uzaktan eğitime ilişkin görüşleri ile ilgili dört araştırma bulunabilmiştir:

Bunlardan birincisi, Genç ve Gümrükçüoğlu (2020) tarafından yapılan Koronavirüs (Covid-19) sürecinde İlâhiyat Fakültesi öğrencilerinin uzaktan eğitime bakışlarını konu alan araştırmadır. Bu araştırmada veriler, 14 İlahiyat Fakültesinin 1212 öğren- 
cisinden anket ve yarı yapılandırılmış mülakat yoluyla toplanmışır. İkincisi, Koç (2020) tarafından yapılan ve Covid-19 salgını sürecinde İlahiyat Fakültesi öğretmenlik uygulaması dersinin uzaktan eğitim yoluyla yapılmasını konu alan araştırmadır. Verilerin, nicel ve nitel veri toplama araçlarıyla elde edildiği araştırmanın çalışma grubu, 26 öğretmen adayı ve öğretmen adaylarının derslerini uzaktan eğitim yoluyla takip eden 150 öğrenciden oluşmaktadır. Katılımcı öğretmen adayları, Yakın Doğu Üniversitesi İlâhiyat Fakültesi son sınıf öğrencilerinden seçilmiştir. Üçüncüsü, Genç ve diğerleri (2021) tarafından yapılan ve ilahiyat alanında lisansüstü eğitim gören öğrencilerin, uzaktan eğitimle ilgili görüsslerini konu edinen araştırmadır. Bu araştırmada da veriler 7 farklı üniversitede ilahiyat alanında lisansüstü eğitim gören 145 öğrenciden anket ve mülakat yoluyla elde edilmiştir. Dördüncüsü ise, Selçuk ve diğerleri (2021) tarafından yapılan, ilahiyat öğrencilerinin uzaktan eğitim deneyimlerine yönelik görüşlerini ele alan araştırmadır. Veriler 3 İlahiyat Fakültesinden 594 öğrenciye uygulanan “Çevrimiçi Öğrenme Tutum ölçeği” ile elde edilmiştir.

Öğrenci görüşlerini metaforlar yoluyla tespit etmeye yönelik çalışmaya rastlanmamıştır. Bu araştırma yukarıda belirtilen araştırmalardan farklı olarak, bahsi geçen çalışmalarda örneklem grubuna dâhil edilmeyen Kilis 7 Aralık Üniversitesi İslami İlimler Fakültesi öğrencileriyle gerçekleştirilmiştir. Araştırma yöntemi de yine diğer araştırmalardan farklı olarak nitel araştırma desenlerinden olan olgubilim (fenomenoloji) deseninde tasarlanmıştır. İlahiyat/İslami ìlimler Fakültesi öğrencilerinin uzaktan eğitim kavramına yönelik algılarını metaforlar yoluyla belirleyerek, uzaktan eğitim faaliyetlerinin niteliğinin geliştirilmesi konusunda katkı sağlayacağı düşünülmektedir.

Bu araştırma, Kilis 7 Aralık Üniversitesi İslami İlimler Fakültesi örneğinden hareketle yükseköğretim öğrencilerinin uzaktan eğitim kavramına ilişkin algılarının metaforlar yoluyla ortaya konulmasını amaçlamaktadır. Çalışmada bu genel amaç çerçevesinde aşağıdaki sorulara cevap aranmıştır.

1. İslami İlimler fakültesi öğrencilerinin uzaktan eğitim kavramına ilişkin sahip oldukları metaforlar nelerdir?

2. Öğrenciler tarafından oluşturulan metaforlar ortak özellikleri bakımından hangi tema ve alt temalar altında toplanabilir?

3-Bu kavramsal temalar katılımcıların cinsiyeti, sınıf düzeyi ve eğitime katıldıklarl yere göre farklllık göstermekte midir?

\section{Yöntem}

Yöntem bölümünde araştırmanın deseni, katılımcılar, veri toplama aracı ve verilerin analizi yer almaktadır.

\subsection{Araştırmanın Deseni}

İslami İlimler Fakültesi örneğinden hareketle yükseköğretim öğrencilerinin uzaktan eğitim kavramına ilişkin algılarını metaforlar yoluyla belirlemeyi amaçlayan bu çalışma nitel araştırma desenlerinden, olgubilim (fenomenoloji) deseninde tasarlan- 
mıştır. Olgubilim deseninde farkında olunan fakat mahiyeti hakkında, derin ve ayrıntı sahibi olunamayan olgulara odaklanılır (Şimşek - Yıldırım, 2013). Bu desen, eğitim araştırmalarında eğitim paydaşlarının belli bir fenomene yönelik deneyimlerini, alg1larını ve duygularını somutlaştırmak amacıyla kullanıldı̆̆ı (Polatcan - Kılıç, 2018) için tercih edilmiştir.

\subsection{Araştırmanın Katılımcıları}

Araştırmanın katılımcılarını, 2020-2021 öğretim yılında Kilis 7 Aralık Üniversitesi İslami İlimler Fakültesinde öğrenim görmekte olan öğrenciler oluşturmaktadır. 230 öğrenciden veri alınmış ancak yapılan analizlerdeki elemeler sonunda değerlendirmeye alınan katılımcı sayısı 197 öğrenci olarak belirlenmiştir. Katılımcı özellikleri Tablo 1'de verilmiştir. Örneklem seçiminde amaçlı örneklem yöntemlerinden biri olan ölçüt örnekleme yöntemi esas alınmıştır (Şimşek - Yıldırım, 2013). Katılımcı seçiminde ölçüt, araştırma amacına dayalı olarak 2020-2021 öğretim yılında, derslerini uzaktan eğitimle alan, farklı sınıf düzeyinde eğitim gören kız ve erkek İslami İlimler Fakültesi öğrencileri olarak belirlenmiştir.

Tablo 1. Araştırmaya Katılan Öğrencilerin Kişisel Özellikleri

\begin{tabular}{llll}
\hline Özellik & Grup & f & \% \\
\hline Cinsiyet & Kadın & 135 & 68,5 \\
\cline { 2 - 4 } & Erkek & 62 & 31,5 \\
\cline { 2 - 4 } & Toplam & 197 & 100,0 \\
\hline Uzaktan Eğitime & Köy & 56 & 28,4 \\
\cline { 2 - 4 } Katıldığı Yer & İç̧e & 45 & 22,8 \\
\cline { 2 - 4 } & İl & 96 & 48,7 \\
\cline { 2 - 4 } & Toplam & 197 & 100,0 \\
\hline Sinıf & 1.Sinıf & 70 & 20,3 \\
\cline { 2 - 4 } & 2.Sınıf & 38 & 37,6 \\
\cline { 2 - 4 } & 3.Sinıf & 45 & 22,8 \\
\cline { 2 - 4 } & 4. Sinıf & 197 & 100,0 \\
\hline
\end{tabular}

Tablo 1'e göre, katılımcı öğrencilerin \%68,5'i kız öğrencilerden \%31,5'i ise erkek öğrencilerden oluşmaktadır. Okul yönetiminden alınan bilgilere göre bütün öğrenciler arasındaki kız-erkek oranının da örnekleme yakın olduğu bilgisi alınmıştır. Öğrencilerin yarıya yakınını il merkezlerinden uzaktan eğitime katılanlar oluşturmaktadır. Katılımcı öğrencilerden 1, 3 ve 4. sınıf öğrenci sayıları birbirine yakınken 2. sınıfta okuyan katılımcıların diğerlerinden daha fazla olduğu görülmektedir.

\subsection{Verilerin Toplanması}

Kilis 7 Aralık Üniversitesi Rektörlüğü Etik kurulunun, 23/03/2021 tarih ve 2021/08 sayılı kararı ile veri toplamak için izin alınmıştır. Veriler "Uzaktan eği- 
tim......gibidir. Çünkü........" ifadesindeki boşluklara, uygun bir metafor ve metaforun gerekçesini yazmalarının istendiği yarı yapılandırılmış form kullanılarak toplanmıştır. Yarı yapılandırılmış bu form öğrencilere elektronik ortamda gönderilerek, öğrencilerden formun doldurulması istenmiştir. Öğrenciler tarafından doldurulduktan sonra geri gönderilen formlar, bu araştırmada temel veri kaynağı olarak kullanılmıştır. Veriler 24/03/2021 ile 25/04/2021 tarih aralığında toplanmıştır.

\subsection{Verilerin Analizi}

Nitel verilerin analizi; ayıklama, tema ve alt temalara ayırma ve SPSS programina aktarma şeklinde üç aşamada gerçekleştirilmiştir. Tema ve alt temalara ayırma işlemi içerik analizi yoluyla yapılmıştır (Şimşek - Yıldırım, 2013). Verilerin kategori ve tema olarak sınıflandırılması konusunda literatürde kapsam yönünden farklı bilgi ve uygulamalar bulunmaktadır (Çelik vd., 2020; Diler, 2020; Meydan, 2020; Saban, 2008). Bundan dolayı, bu çalışmada metaforlar tema ve alt temalar şeklinde sınıflandırılmıştır. Ayıklama aşamasında 230 öğrenciden gelen formların tamamı okunmuştur. Gerekçesiyle birlikte bir metafor yazılmamış olan formlar elenmiştir. "Biraz sıkıntılı ama güzel.", "Gayet güzel uzaktan eğitim", "Verimli gibidir ama değildir." örneklerinde olduğu gibi herhangi bir metafor yazmadan uzaktan eğitimle ilgili düşüncelerini ifade eden katılımcıların formları değerlendirilmeye alınmamıştır. Ayrıca sadece bir metafor yazıp, gerekçelendirmeyen bazı öğrencilerin formları da değerlendirilmeye alınmamıştır. İkinci aşamada 33 tanesi elenerek 197’ye düşürülen metaforlar bir Excel dosyasına aktarılarak alfabetik sıraya göre dizilmiştir. Araştırmacı ile birlikte din eğitimi ve din felsefesi alanı uzmanı iki akademisyene daha dosyalar verilerek, üretilen metaforların gerekçelerine bakarak hangi tema ve alt temalar altında sınıflandırılabileceğinin yazılması istenmiştir. Daha sonra bir araya gelen bu üç uzman tarafından metaforlarla ilgili oluşturulan tema ve alt temalar tartışılmıştır. Akademisyenlerin çoğunlukla benzer tema ve alt temalar ürettikleri belirlenmiştir. Sentetik ve yapay gibi eş anlamlı alt temalar "yapaylık" alt temasında birleştirilmiştir. Birleștirilemeyen fakat iki alt temayı da ifade eden yakın alt temalar iki isimli halde yazılmıştır. Örneğin hem uzaklık hem de özlem alt temasını ifade eden metaforlara "uzaklık ve özlem" alt teması adı verilmiştir. Bu şekilde oluşturulan 11 alt tema, alt temaların ifade ettikleri anlamlara göre "olumlu" ve "olumsuz" olmak üzere iki tema şeklinde sınıflandırılmıştır. Akademisyenlerin belirlediği alt temalar arasındaki tutarlığın hesabında Miles ve Huberman formülü kullanılmıştır (Baltacı, 2017). [Güvenirlik =Görüş Birliği Sayısı / (Toplam Görüş Birliği + Görüş Ayrilığı Sayısı) x 100]. Bu formüle göre alt temaların uyum yüzdesi \%96 olarak belirlenmiştir. Bu sonuç yüksek bir güvenirlik olarak değerlendirilmektedir (Baltac1, 2017).

Araştırmanın geçerliğini sağlamak için, toplanan veriler ayrıntılı olarak raporlanmış ve sonuçlara nasıl ulaşıldığı bütün aşamaları ile açıklanmıştır. Ayrıca araştırma bulgularının başka araştırma sonuçlarıyla karşılaştırmaları yapılmıştır (Şimşek Yıldırım, 2013). Bulgular bölümünde sadece veriler ortaya konulmuş, bulguların yorumları ve karşılaştırmaları sonuç ve tartışma bölümünde yapılmıştır. Üçüncü 
aşamada katılımcı özellikleri, metaforlar, tema ve alt temalar SPSS.25 programına aktarılarak metafor, tema ve alt temalara ait frekans ve yüzde hesaplamaları yapılmış, ayrıca bağımsız değişkenlere ait çapraz tablolar oluşturulmuştur.

197 metafordan oluşturulan 11 alt temayı en iyi temsil edecek metaforlar ve açılamaları belirlenip, bulgular kısmında örnek metafor olarak verilmiştir. Örnek metafor ifadelerinin sonuna katılımcı özellikleri kısaca yazılmıştır. Örnek olarak; (27- Er, 2, Köy) ifadesinde, ilk sıradaki sayı, katılımcı sırasını, ikinci sıradaki ifade cinsiyeti, üçüncü sıradaki sayı katılımcının sınıf düzeyini ve dördüncü sıradaki ifade, katılımcının uzaktan eğitime katıldığı yeri belirtmektedir.

\section{Bulgular}

Bu bölümde örneklem grubundaki öğrencilerin uzaktan eğitime ilişkin ürettikleri metaforlara, metaforlardan oluşturulan tema, alt tema ve temalar arasındaki karşılaştırmalara yer verilmiştir.

\subsection{Uzaktan Eğitim Kavramına İlişkin Oluşturulan Tema ve Alt Temalar}

Uzaktan eğitim kavramina ilişkin 197 öğrencinin ürettiği 167 farklı metafor, 11 alt tema ve 2 farklı tema altında toplanmıştır. Bu bölümde, geliştirilen 2 temaya ait frekans ve yüzdeler tablo halinde sunulmuş daha sonra bu temalarla ilgili öğrenci ifadelerine yer verilmiştir.

Uzaktan eğitim kavramına ilişkin geliştirilen tema ve alt temalara ait frekans ve yüzde değerleri Tablo 2'de sunulmuştur.

Tablo 2. Uzaktan Eğitim Konusunda Üretilen Metaforların Tema ve Alt Temalara Göre Dağılımı

\begin{tabular}{|c|c|c|c|}
\hline Tema & Alt temalar & Metaforlar & $\begin{array}{l}\text { Alt temalara yönelik } \\
\text { örnek metaforlar }\end{array}$ \\
\hline \multirow[b]{2}{*}{ 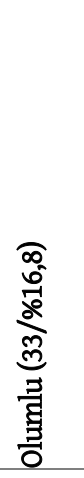 } & $\begin{array}{l}\text { Avantaj } \\
(20 / \% 10,2)^{5}\end{array}$ & $\begin{array}{l}\text { Bal (4), Kaymaklı bal (2), Kendimizi } \\
\text { geliştirmede bir araç (2), Açık öğre- } \\
\text { tim sistemi, Can, Çantadaki keklik, } \\
\text { Çınar ağacı, Derde derman, Fırsat, } \\
\text { Joker, Meyve ağacı, Pamuk, Rüzgâr, } \\
\text { Tatlı, Teknolojik bir okul. }\end{array}$ & $\begin{array}{l}\text { Uzaktan eğitim kay- } \\
\text { maklı bal gibidir. Çün- } \\
\text { kü iki zevki aynı anda } \\
\text { yaşarız hem okuyoruz } \\
\text { hem de evdeyiz (180- } \\
\text { Er, } 4 \text {, ìl). }\end{array}$ \\
\hline & $\begin{array}{l}\text { Gerekli } \\
(13 / \% 6,6)\end{array}$ & $\begin{array}{l}\text { Annelik yapmak, Bitki, Boya, Elekt- } \\
\text { rikli süpürge, İlaç, Kaçak çay, Kuru } \\
\text { toprağa fidan ekmek, Oksijen, Okul, } \\
\text { Ressamın tablosu. Su, Tuz. Yüksek } \\
\text { lisans. }\end{array}$ & $\begin{array}{l}\text { Uzaktan eğitim oksijen } \\
\text { gibidir. Çünkü oksijen } \\
\text { öğrencinin vazgeçil- } \\
\text { mezdir (113-Er, } 4 \text {, İlçe). }\end{array}$ \\
\hline 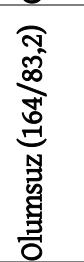 & $\begin{array}{l}\text { Aldatıcı } \\
(44 / \% 22,3)\end{array}$ & $\begin{array}{l}\text { Davul (5), Kurtlu ceviz (2), Tuzsuz } \\
\text { yemek (2), Acı biber, Amelsiz alim, } \\
\text { Araba, Ay, Balon, Biber, Boş ceviz, } \\
\text { Cam, Çalı, Deniz, Dış görünüş, Erik, } \\
\text { Galaksi, Ham çilek, Harabe ev, } \\
\text { Kapitalizm, Kelek kavun, Kırmızı }\end{array}$ & $\begin{array}{l}\text { Uzaktan eğitim kurtlu } \\
\text { ceviz gibidir, dışarıdan } \\
\text { güzel gözükür ama içi } \\
\text { boştur. (27- Er, 2, Köy). }\end{array}$ \\
\hline
\end{tabular}

\footnotetext{
${ }^{5}$ Parantez içindeki ilk rakam kişi sayısını, ikinci rakam yüzdeyi ifade etmektedir.
} 
biber, Kokusuz çiçek, Limon, Meyan

kökü şerbeti, Online alışveriş, Oyun,

Pamuk şekeri, Plastik çiçek, Rubik

küp, Rüya, Sahte çiçek, Sözleşme

imzalamak, Şehir hayatı, Turşu

suyu, Uzaktan hoş, Vitrin, Yan

sanayi ürünü, Yaz güneşi.

Verimsiz Hastane yemeği (2), Kış güneşi (2), Uzaktan eğitim düzen-

(41/\%20,8) Zombi (2), Boş başak, Boş ceviz, siz uyku gibidir çok

Cips, Çay, Çerez, Çiçeksiz bahçe, uyusan da verim alaÇürük meyve, Dalsız ağaç, Düzensiz mazsın. (92- Kız, 3, uyku, Eğitim tür, Eğitim yöntemi, Köy).

Ekmek, Emzik, Fastfood, Fistıksız baklava, Film izlemek, Güneşlenmeyen bir ev, Hasta iken yemek yemek, Hayallerim, Klorlanmış su, Kötü üvey anne, Kuru tarla, Mum, Serada yetişmiş bir ürün, Soğuk çay, Susuz toprak, Şişmiş balon, Tatsız yemek, Tuzsuz pilav, Tuzsuz yemek, Verim vermeyen ekin, Vişneli çikolata, Yanlış saat, Yetersiz, Yırtılmış elbise.

Zorlayıcı Zorlu süreç (2), Ayva, Bozuk yemek, Uzaktan eğitim işkence $(19 / \% 9,6) \quad$ Ceza hukuku, Çobansız sürü, Ev, gibidir. Çünkü hocalaHafta sonu tatili, İşkence, Kedinin rımız çok fazla ödev ciğere bakması, Kış, Mafya, Mum, veriyor.” (122-Kız,3, il) Öğretmenlik, Sarf dersi, Çölde su aramak, Uçsuz bucaksız yol, Uykudan uyanmak, Zulüm.

Etkisiz Balon (2), Boş bir kutu (2), Boş arsa, "Uzaktan eğitim sol-
$(18 / \% 9,1) \quad$ Boş çerçeve, Boş defter, Boş teneke, muş bitkiye sonradan Çakma vitaminler, Eziyet, Solmuş inen yağmur gibidir. bitkiye sonradan inen yağmur, Çünkü hiçbir faydası Materyalist düşünce, Ot, Pırasa, yoktur.” (53-Kız, 2, Saman, Somalilliler, Tek kanatlı kuş, Köy). Televizyon.

Uzaklıkve Ağaçsız orman, Ağaçtaki meyve, Uzaktan eğitim yıldız Özlem Camın ardındaki bardak, Fotoğraf, gibidir bakarsın ama (13/\%6,6) Görüntülü konuşma, Gurbet, Gur- dokunamazsın. (57- Kız, bette olmak, İmtihan, Sevgisiz 3, Ill). kalmış bir yavru, sılamız, Sudan çıkmış balık gibi hissetmek, Şekersiz çay, Yıldız.

Yapay Plastik meyve (5), Hormonlu sebze, Uzaktan eğitim plastik (13/\%6,6) Internet kokusu, Plastik çiçek, çiçek gibidir. Vardır 


\begin{tabular}{|c|c|c|}
\hline & $\begin{array}{l}\text { Robot, Sahte çiçek, Yapay, Yapay } \\
\text { çiçek, Yapay evren. }\end{array}$ & $\begin{array}{l}\text { ama gerçek değildir } \\
\text { (21-Er, 2, İlçe). }\end{array}$ \\
\hline $\begin{array}{l}\text { Belirsizlik } \\
(7 / \% 3,6)\end{array}$ & $\begin{array}{l}\text { Buzdağı(nın) görünmeyen kısmı (2), } \\
\text { Kavanoz, Kara sevda, Sonu görün- } \\
\text { meyen yol, Kılavuzsuz din, Pişma- } \\
\text { niye }\end{array}$ & $\begin{array}{l}\text { Uzaktan eğitim buz } \\
\text { dağının görünmeyen } \\
\text { kısmı gibidir. Çünkü } \\
\text { sonu nereye kadar } \\
\text { gidecek bilmiyoruz (39- } \\
\text { Kız, 4, İlçe). }\end{array}$ \\
\hline $\begin{array}{l}\text { Geçici } \\
(5 / \% 2,5)\end{array}$ & $\begin{array}{l}\text { Canlı gül, Greyfurt, Konuşulan } \\
\text { konu, Parfüm, Şeker. }\end{array}$ & $\begin{array}{l}\text { Uzaktan eğitim parfüm } \\
\text { gibidir. Çünkü kokusu } \\
\text { güzeldir fakat kalıc1 } \\
\text { değildir (78- Kız, 2, ̇̇l). }\end{array}$ \\
\hline $\begin{array}{l}\text { Eşitsizlik } \\
(4 / \% 2,0)\end{array}$ & Verimsizlik (2), Deniz, Dünya. & $\begin{array}{l}\text { Uzaktan eğitim Dünya } \\
\text { gibidir. Çünkü imkânı } \\
\text { olana güzel olmayana } \\
\text { eziyettir (114- Er, 3, ìl). }\end{array}$ \\
\hline
\end{tabular}

Toplam (197/\%100) 28 olumlu metafor+139 olumsuz

metafor tespiti $=167$

Tablo 2'ye göre, uzaktan eğitim konusunda 197 adet metafor üretilmiştir. Bu metaforlardan 147 tanesi birer kişi tarafından, 20 tanesi ise iki ve daha fazla kişi tarafından üretildiğinden toplamda 167 farklı metafor üretilmiştir. Davul ve Plastik meyve metaforu beşer defa, Bal, dört defa, Balon ve Tuzsuz yemek, üçer defa, Boş bir kutu, Boş ceviz, Buzdağı(nın) görünmeyen kısmı, Deniz, Hastane yemeği, Kaymaklı bal, Kendimizi geliştirmede bir araç, Kış güneşi, Kurtlu ceviz, Mum, Plastik çiçek, Sahte çiçek, Verimsizlik, Zombi ve Zorlu süreç metaforları ikişer defa tekrar edilen metaforlardır. Bunların dışındaki metaforlar ise birer kişi tarafından üretilmiştir.

Uzaktan eğitimle ilgili olarak üretilen metaforlar, tanımlamalardaki ortak yönlere bakılarak 11 alt tema halinde gruplandırılmıştır. Bu alt temalardan da olumlu ve olumsuz olmak üzere iki tema oluşturulmuştur. Öğrencilerin ürettikleri metaforlardan 164’ü $(\% 83,2)$ “olumsuz" teması altında, 33’ü (\%16,8) ise "olumlu” teması altında toplanmıştır.

"Olumlu" temasındeki iki alt tema, Avantaj $(20 / \% 10,2)$ ve Gerekli $(13 / \% 6,6)$ alt temalarıdır. Çoğunluğu oluşturan "olumsuz" temasındaki 9 alt tema ise, Aldatıcı (44/\%22,3), Verimsiz (41/\%20,8), Zorlayıcı (19/\%9,6), Etkisiz (18/\%9,1), Uzaklık ve özlem $(13 / \% 6,6)$, Yapay $(13 / \% 6,6)$, Belirsizlik $(7 / \% 3,6)$, Geçici $(5 / \% 2,5)$ ve Eşitsizlik $(4 / \% 2,0)$ alt temalaridir.

2 tema ve 11 alt temaya ait metaforlar ve katılımcı bilgileri katılımcı fazlalı̆̆ı sırasina göre aşağıda sunulmuştur.

\section{2. “Olumsuz" Olarak Uzaktan Eğitim Teması}

Katılımcı öğrencilerin uzaktan eğitimle ilgili ürettikleri metaforlara ait ilk tema “olumsuz” temasıdır. 197 katılımcının 164'ü $(\% 83,2)$ tarafından üretilen metaforlar 
uzaktan eğitimin "olumsuz" teması altında yer almaktadır. Bu temadaki metaforlar 9 alt tema altında toplanmıştır:

\subsubsection{Aldatıc1}

"Olumsuz" temasının ilk alt teması "aldatıcı" alt temasıdır. Bu alt tema öğrenciler tarafından en çok tercih edilen ve metafor üretilen alt tema olmuştur. Katılımcılardan 44'ü $(\% 22,3)$ uzaktan eğitimi aldatıcı olarak tanımlayan metaforlar üretmişlerdir. Öğrenciler tarafından bu alt temayı ifade eden bazı metafor örnekleri şöyledir:

Uzaktan eğitim online alışveriş gibidir. Çünkü sitedeyken güzel geldiğinde ise beklentini karşılamamaktadır." (130-Kı, 1, İl)

"Uzaktan eğitim kurtlu ceviz gibidir, dışarıdan güzel gözükür ama içi boştur." (27- Er, 2, Köy)

"Uzaktan eğitim tuzsuz yemek gibidir. Çünkü görüntü iyi olsa da tadı yanıltır." (36- K1z, 4, Köy)

"Uzaktan eğitim, davul gibidir. Çünkü önce kulağa hoş gelir işin içine girince bambaşka bir boyuta taşınır.” (84-Kız, 2, Köy)

"Uzaktan eğitim, amelsiz alime benzer. Çünkü herkes tarafından faydalanılan biri gibi gözükür ama kendine hayrı olmaz." (120- Er, 2, ill)

$\mathrm{Bu}$ ifadelerden öğrencilerin, uzaktan eğitimin, yüz yüze eğitimin yerini tutmaya ve ona benzemeye çalıştığını fakat tam anlamıla onun özelliklerine sahip olamadığını düşündükleri anlaşılmaktadır.

\subsubsection{Verimsiz}

"Olumsuz" temasının ikinci alt teması "verimsiz" alt temasıdır. Katılımcılardan 41'i (\%20,8) uzaktan eğitimi verimsiz olarak tanımlayan metaforlar üretmişlerdir. Bu alt temayı ifade eden metaforların öğrenciler tarafından tanımlamalarına ilişkin şu örnekler verilebilir:

“Uzaktan eğitim, kuru tarla gibidir çünkü verimsizdir." (22- Kız, 4, İlçe)

"Uzaktan eğitim ekmek gibidir. Karın doyursa bile vücudun ihtiyaçlarını karşılamakta yetersizdir." (28- K1z, 3, Il)

"Uzaktan eğitim kış güneşi gibidir. Çünkü 1şığını yayar ama 1sıtmaz." (65- Kız, 2, il)

"Uzaktan eğitim düzensiz uyku gibidir çok uyusan da verim alamazsın." (92- Kız, 3, Köy)

"Uzaktan eğitim verim vermeyen ekin gibidir. Çünkü ektiklerimizi biçemiyoruz maalesef." (136- K1z, 1, Köy)

Verimsiz alt temasında üretilen metaforlar ve gerekçelerine göre, öğrencilerin uzaktan eğitimin görünürde işlevlerini yerine getirdiğini fakat sonuçta istenen verimin alınamadığını ifade ettikleri görülmektedir.

\subsubsection{Zorlayıc1}

"Olumsuz" temasının üçüncü alt teması "zorlayıcı" alt temasıdır. Katılımcıların 19’u $(\% 9,6)$ uzaktan eğitimi zorlayıcı olarak tanımlayan metaforlar üretmişlerdir. Bu alt temayı ifade eden bazı örnek metaforlar aşağıda yer almaktadır:

"Uzaktan eğitim işkence gibidir. Çünkü hocalarımız çok fazla ödev veriyor." (122$\mathrm{K} 1 \mathrm{z}, 3, \mathrm{Il})$ 
“Uzaktan eğitim sarf dersi gibidir. Çünkü az görünür çok çektirir.” (145- Kız, 3, ill)

"Uzaktan eğitim çölde su aramak gibidir. Çünkü bu kadar büyük bilgi çölünde doğru bilgiyle hemhal olmak çölde su aramaya benziyor.” (167- Kız, 4, İlçe)

"Uzaktan eğitim zulüm gibidir. Çünkü bu zorlu süreçte evde çalışılmıyor ve internet sıkıntısı var." (169-Kız, 1, İlçe)

"Uzaktan eğitim uçsuz bucaksız yol gibidir. Çünkü bitmez sıkıntıları var.” (4- Er, 1, Köy)

Zorlayıcı alt temasında katılımcı öğrenciler, ders yükü yoğunluğu, evde ders çalışmanın zorluğu ve uzaktan eğitime erişim araçlarıyla ilgili sıkıntılardan dolayı uzaktan eğitimin zorluğunu ifade etmişlerdir.

\subsubsection{Etkisiz}

"Olumsuz" temasının dördüncü alt teması "etkisiz" alt temasıdır. Katılımcılardan 18'i $(\% 9,1)$ uzaktan eğitimi etkisiz olarak tanımlayan metaforlar üretmişlerdir. Bu alt temayı ifade eden bazı örnekler şöyledir:

"Uzaktan eğitim solmuş bitkiye sonradan inen yağmur gibidir. Çünkü hiçbir faydası yoktur." (53-K1z, 2, Köy)

"Uzaktan eğitim boş çerçeve gibidir. Çünkü neden alındı̆̆ bilinmeyen fazladan bir eşyadır." (91- Er, 1, ill)

"Uzaktan eğitim tek kanatlı kuş gibidir. Çünkü çok çaba harcasa da uçamaz." (101- Kız, 3, il)

"Uzaktan eğitim ot gibidir çünkü çoktur ama faydası yoktur. Yani yüz yüze anlatımin yarısı kadar olmaz." (159- Er, 4, Köy)

"Uzaktan eğitim çakma vitaminler gibidir çünkü bu vitaminleri kullanırsınız ama hiç faydasını görmezsiniz.” (153- Kız, 1, Köy)

Yukarıdaki ifadelerden öğrencilerin, uzaktan eğitim uygulamalarındaki çabaların hiçbir işe yaramadı̆̆ını ve gereksiz olduğunu düşündükleri anlaşılmaktadır.

\subsubsection{Uzaklik ve Özlem}

"Olumsuz" temasının beșinci alt teması "uzaklık ve özlem" alt temasıdır. Katılımcılardan 13'ü $(\% 6,6)$ uzaktan eğitimi uzaklık ve özlem olarak tanımlayan metaforlar üretmişlerdir. Bu alt temayı ifade eden metaforlar şöyle örneklendirilebilir.

"Uzaktan eğitim bizim sılamız gibidir. Çünkü okula, hocalarımıza, ilim yuvamıza çok uzağız. Şimdi bizlere düşen vuslatı dilemektir.” (56- Kız, 4, ill)

"Uzaktan eğitim yıldız gibidir bakarsın ama dokunamazsın." (57- Kız, 3, il)

"Uzaktan eğitim ağaçtaki meyve gibidir çünkü seversin, almak istersin ama ulaşamazsın.” (73- Er, 2, Köy)

"Uzaktan eğitim, sudan çıkmış balık gibi hissetmek gibidir. Çünkü hocalarımızdan ders almak varken uzaktan eğitimle cansız ve ruhsuz bilgisayar ekranlarına, A4 kağıtlarına, ödevlere mahkûm olduk." (195- Kız, 4, İlçe)

"Uzaktan eğitim fotoğraf gibidir. Çünkü görünüyor ama asla dokunulamıyor." (55- K1z, 4, Köy)

$\mathrm{Bu}$ alt temada öğrenciler, uzaktan eğitimin, eğitim ortamındaki sosyalleşme eksikliğini ortaya koymuşlar ve yüz yüze eğitimdeki öğrenme ortamına ve hocalarına olan özlemlerini dile getirmişlerdir. 


\subsubsection{Yapay}

"Yapay" alt teması "olumsuz" temasinın altıncı alt temasıdır. Katılımcılardan 13 'ü $(\% 6,6)$ uzaktan eğitimi yapay olarak tanımlayan metaforlar üretmişlerdir. Bu alt temaya ilişkin bazı metafor örnekleri şöyledir:

"Uzaktan eğitim robot gibidir. Çünkü öğrenciye dersi anlatır ama öğrenciyi anlayamaz.” (132- Kız, 1, Köy)

"Uzaktan eğitim plastik çiçek gibidir. Vardır ama gerçek değildir." (21- Er, 2, İlçe)

"Uzaktan eğitim sahte çiçek gibidir görüntüsü var ama kokusu yoktur." (172- Kız, 1 , İlçe)

“Uzaktan eğitim plastik meyve gibidir görüntüsü iyidir tadı yoktur." (182- Er, 1, İlçe)

"Uzaktan eğitim yapay çiçek gibidir. Çünkü kokusu yoktur." (85- Kız, 2, Köy)

$\mathrm{Bu}$ alt temadaki öğrenci ifadeleri incelendiğinde, uzaktan eğitimin, yüz yüze eğitiminin yerine tutmaya çalş̧an fakat onun yerini tutamayacak olan bir yapay öğrenme şekli olduğu ile ilgili görüşlerini dile getirildiği görülmektedir.

\subsubsection{Belirsizlik}

"Belirsizlik" alt teması, "olumsuz" temasının yedinci alt temasıdır. Katılımclardan 7'si $(\% 3,6)$ uzaktan eğitimi belirsizlik olarak tanımlayan metaforlar üretmişlerdir. Bu alt temayla ilgili bazı metafor örnekleri aşağıda verilmiştir:

"Uzaktan eğitim buz dağının görünmeyen kısmı gibidir. Çünkü sonu nereye kadar gidecek bilmiyoruz." (39- Kız, 4, İlçe)

"Uzaktan eğitim kılavuzsuz din gibidir. Çünkü kimin nereye savrulacağı belli değil." (86- Er, 4, İl)

“Uzaktan eğitim kara sevda gibidir. Çünkü ne zaman biteceği belli değil.” (6- Er, 2, Köy)

"Uzaktan eğitim sonu görünmeyen yol gibidir. Çünkü biraz ümitlisin ama sonunda ne var bilmiyorsun." (11- Kız, 4, il)

"Uzaktan eğitim kavanoz gibidir. Çünkü dıştan kapalı gözükür içi belli olmaz." (1Erkek, 1, il)

$\mathrm{Bu}$ alt temada öğrenciler uzaktan eğitimin, niteliği tam olarak belli olmadığı için nereye savrulacağı bilinemeyen ve akıbeti hakkında endişelerinin olduğu bir belirsizlik taşıdığına dikkat çeken ifadelere vermişlerdir.

\subsubsection{Geçici}

"Olumsuz" temasının sekizinci alt teması ise "geçici" alt temasıdır. Katılımcılardan 5’i (\%2,5) uzaktan eğitimi geçici olarak tanımlayan metaforlar üretmişlerdir. Bu alt temayla ilgili bazı metaforlar şöyle örneklendirilebilir:

"Uzaktan eğitim parfüm gibidir. Çünkü kokusu güzeldir fakat kalıcı değildir." (78$\mathrm{K} 1 \mathrm{z}, 2$, Il)

"Uzaktan eğitim canlı gül gibidir. İlk görünümü estetik iken solunca hiçbir şeye benzemez kimsenin dikkatini çekmez." (3- Er, 2, il)

"Uzaktan eğitim şeker gibidir. Çünkü uzaktan çok hoş gözüküp, tadıldığında ise anlık ve geçicidir tadı." (51- Kız, 2, il) 
Yukarıdaki ifadeler incelendiğinde, uzaktan eğitimin, pandemi sürecinde yüz yüze eğitimin yerine zorunlu olarak uygulandığı için etkileri ve uygulaması her an sona erebilecek geçici bir durum olarak ifade edildiği görülmektedir.

\subsubsection{Eşitsizlik}

"Eşitsizlik" alt teması," olumsuz" temasının dokuzuncu ve son alt temasıdır. Katılımcılardan 4'ü $(\% 2,0)$ uzaktan eğitimi eşitsizlik olarak tanımlayan metaforlar üretmişlerdir. Bu alt temayı ifade eden bazı metafor örnekleri aşağıda verilmiştir:

"Uzaktan eğitim deniz gibidir, internet kullanmayı bilmeyen boğulur (ya da interneti olmayan) bilen yüzer." (161- Kız, 3, il)

"Uzaktan eğitim dünya gibidir. Çünkü imkânı olana güzel olmayana eziyettir." (114- Er, 3, il)

"Uzaktan eğitim verimsizlik gibidir çünkü her öğrenci aynı imkana sahip değildir. Öğrenci anlamadiği konuyu uzaktan nasıl hocalara sorsun. En verimli eğitim yüz yüze olan eğitimdir." (75- Kız, 2, il)

Bu alt temada öğrenciler uzaktan eğitimi, gerekli olan araç-gereç ve bunların kullanım bilgisine sahip olma durumuna göre herkesin farklı düzeylerde yararlanabildiği, eşitsiz bir durum olarak nitelendirmişlerdir.

\section{3. "Olumlu" Olarak Uzaktan Eğitim Teması}

Katılımcı öğrencilerin uzaktan eğitimle ilgili ürettikleri metaforlara ait ikinci tema "olumlu" temasıdır. 197 katılımcının 33’ü $(\% 16,8)$ tarafından üretilen metaforlara uzaktan eğitimin "olumlu" teması altında yer verilmiştir. Bu temadaki metaforlar olumlu anlam ifade eden 2 alt tema altında toplanmıştır.

\subsubsection{Avantaj}

"Olumlu" temasının ilk alt teması "avantaj" alt temasıdır. Katılımcilardan 20'si $(\% 10,2)$ uzaktan eğitimi avantaj olarak tanımlayan metaforlar üretmişlerdir. Bu alt temayı ifade eden bazı örnekler şöyledir:

"Uzaktan eğitim kaymaklı bal gibidir. Çünkü iki zevki aynı anda yaşarız hem okuyoruz hem de evdeyiz." (180- Er, 4, il)

"Uzaktan eğitim joker gibidir. Çünkü derslerimizden ayrılmadık ve bu bizim için çok büyük bir avantaj." (87- Kız, 2, Köy)

"Uzaktan eğitim kendimizi geliştirmede bir araç gibidir. Çünkü öğrenciler okula devam edemese de uzaktan eğitimle bu açığı kapatabilmektedir. Bu sisteme öğretmenler konuyla ilgili slayt, makale, deneme vs. yükleyerek öğrencilerin kendilerini geliştirmesine katkıda bulunmaktadır." (131- Kız, 2, Il)

"Uzaktan eğitim bal gibidir. Çünkü sevmediğimiz kişilerin yüzünü görmediğimiz için daha tatlı ve güzel oluyor." (143- Kız, 1, İlçe)

"Uzaktan eğitim tatlı gibidir. Çünkü lezzetlidir." (83- Er, 3, Köy)

$\mathrm{Bu}$ alt temada öğrenciler uzaktan eğitimin kendilerine hem evde olmanın konforunu hem de öğrenime devam etmenin avantajını sağladığını ifade etmişlerdir. Ayrıca yüz yüze öğrenme ortamının bazı olumsuzluklarını da yaşamadıklarını dile getirmişlerdir. 


\subsubsection{Gerekli}

"Olumlu" temasının ikinci alt teması "gerekli" alt temasıdır. Katılımcılardan 13’ü $(\% 6,5)$ uzaktan eğitimi gerekli olarak tanımlayan metaforlar üretmişlerdir. Bu alt temayı ifade eden metaforların öğrenciler tarafından tanımlamalarına ilişkin bazı örnekler şöyledir:

“Uzaktan eğitim oksijen gibidir. Çünkü oksijen (bilgi) öğrencinin vazgeçilmezdir." (113- Er, 4, İlçe)

"Uzaktan eğitim su gibidir. Çünkü görüntüsü tadı olmasa bile bizi hayata bağlar." (63-2, Kız, Köy)

"Uzaktan eğitim elektrikli süpürge gibidir. Çünkü sesi rahatsız eder ama mecbursundur." (147- Kız, 1, il)

Gereklilik alt temasında öğrenciler uzaktan eğitimi, kendi tercihleri olmasa bile pandemi sürecinde yüz yüze eğitimin yerini doldurması ve eğitimde kesinti yaşanmaması için bir gereklilik olarak dile getirmişlerdir.

Uzaktan eğitimle ilgili öğrenci görüşlerinin cinsiyet, sınıf düzeyi ve uzaktan eğitime katılma yerlerine göre durumu aşağıdaki tabloda verilmiştir.

Tablo 3. Uzaktan Eğitimle İlgili Temaların Bazı Değişkenlere Göre Dağılımlarını Gösteren Çapraz Tablo

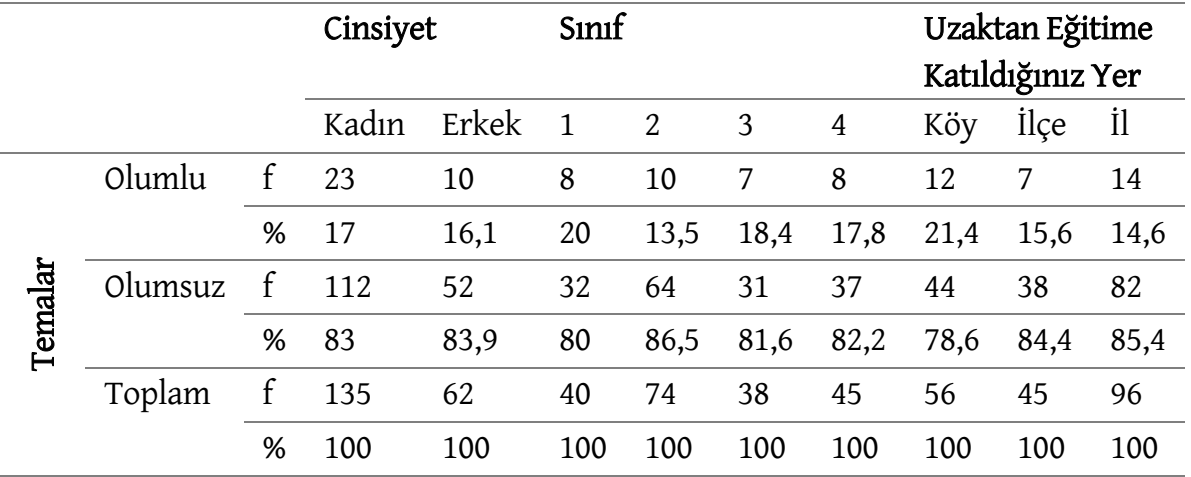

Tablo 3'e göre, uzaktan eğitimle ilgil temaların cinsiyete göre dağılım verileri benzer çıkmıştır. Öğrencilerin sınıf düzeyleri ile ilgili verilere göre, 1, 3 ve 4. sınıf öğrenci görüşleri benzer dağılım gösterirken 2. sınıf öğrencileri diğer sınıflara göre daha fazla olumsuz metafor üretmişlerdir. Öğrencilerin uzaktan eğitime katıldıkları yerleşim yerine göre üretilen metaforların dağılımları incelendiğinde ise, köylerdeki internet erişimi ve uzaktan eğitim araçlarının sınırlılıkları düşünüldüğünde beklenenin aksine köyden katılanların diğer yerleşim yerlerinden katılanlara göre daha fazla olumlu görüş belirttikleri görülmektedir. Bu veriden hareketle öğrencilerin bulundukları yerleşim yerlerinde uzaktan eğitime ulaşım konusunda kayda değer sorunlar yaşanmadığı söylenebilir. Ayrıca pandemi döneminde öğrenci kredi ve burslarının ödenmesine devam edilmesi de öğrencilerin hem uzaktan eğitim araçları edinmelerine kolaylık sağlamakta hem de köyden şehre ulaşım, yurt, beslenme vb. konulardaki zaman ve maliyet kaybını azaltmaktadır. Bu durum köydeki öğrencilerin uzaktan eğitim konusuna olumlu bakmasında etken olabilir. 


\section{Sonuç Tartışma ve Öneriler}

\subsection{Sonuç ve Tartışma}

2020-2021 öğretim yılında yapılan bu araştırma, Kilis 7 Aralık Üniversitesi İslami İlimler Fakültesi örneğinden hareketle yükseköğretim öğrencilerinin "uzaktan eğitim” kavramına yönelik metaforik algılarını belirlemek amacıyla yapılmıştır. Daha önce İlahiyat/İslami İlimler Fakültesi öğrencilerinin uzaktan eğitime yönelik görüşlerini belirlemeye yönelik metafor çalışmasına araştırmalarımız sonucu rastlanmamıştır. Bununla birlikte, pandemi döneminde, ilahiyat alanındaki yükseköğretim öğrencilerinin uzaktan eğitime ilişkin görüşleri ile ilgili dört araştırma tespit edildiği yukarıda ifade edilmiştir. Ayrıca yükseköğretim öğrencilerinin uzaktan eğitime yönelik görüşleri ile ilgili çalışmalar bulunmaktadır. Bu çalışmalardan bazıları da öğrenci görüşlerinin metaforlar yoluyla belirlenmesini esas almaktadır. Dolayısıyla bu araştırmada elde edilen sonuçlar, İlahiyat Fakültesi öğrencilerinin pandemi döneminde uzaktan eğitimle ilgili görüşlerini ele alan bu dört araştırma ve diğer yükseköğretimde uzaktan eğitim konulu araştırmalarla karşılaştırmalı olarak tartışılmıştır.

Uzaktan eğitimle ilgili araştırmalar incelendiğinde araştırmaların üç grupta toplandığı görülmektedir. Birincisi öğrencilerin eğitimi tamamen uzaktan eğitim yoluyla aldıkları, uzaktan eğitim programlarına kayıtlı öğrenci ve öğreticilerle yapılan araştırmalar. İkincisi yüz yüze eğitim öğrencisi iken bazı dersleri uzaktan eğitim yoluyla alan öğrencilerle yapılan araştırmalar. Üçüncüsü ise eğitimlerine yüz yüze eğitim ile devam ederken Covid-19 pandemisi nedeniyle zorunlu olarak uzaktan eğitime geçen öğretici ve öğrencilerle yapılan araştırmalar. Bu araştırma üçüncü gruptaki araştırmalar arasında yer almaktadır. Dolayısıyla eğitim kurumu altyapısı, öğretici, öğrenci nitelikleri ve hazırbulunuşluğu yönüyle farklı olduğu için İlahiyat Lisans Tamamlama (ILITAM) programı öğretici ve öğrencileriyle yapılan araştırmalar, sonuçların karşılaştırılmasında dikkate alınmamıştır.

197 katılımcı öğrenci tarafından, uzaktan eğitimle ilgili 167 farklı metafor üretilmiştir. 20 metafor iki ve daha fazla katılımcı tarafından üretilmiştir. Bunun dışında kalan 147 metafor ise 1 katılımcı tarafından üretilen metaforlardır. Çok sayıda metafor üretilmesi, öğrencilerin uzaktan eğitim olgusu ile ilgili tecrübelerinin yeni olması ve bu konudaki ihtiyaç, sorun ve beklentilerinin farklılaşmasılyla izah edilebilir. Uzaktan eğitimin geleneksel eğitime göre farklı olmasının çok sayıda metafor üretilmesinde etkili olduğu düşüncesi de dile getirilmiştir (Tuncay - Özçınar, 2009). Ayrıca metaforlar, tanımlanmak istenen olgunun tamamını değil, bir yönünü temsil etmektedirler ve dolayısıyla olgunun farklı yönlerine vurgu yapacak çok sayıda metafora ihtiyaç bulunmaktadır (Saban, 2008).

Öğrencilerin ürettikleri metaforların analizi sonrası 2 tema ve 11 alt tema oluşturulmuştur. Oluşturulan metaforlardan 164'ü $(\% 83,2)$ "olumsuz" teması altında, 33’ü $(\% 16,8)$ ise "olumlu" teması altında toplanmıştır. "Olumsuz" temasına ait 9 alt tema Verimsiz, Zorlayıcı, Etkisiz, Uzaklık ve özlem, Yapay, Belirsizlik, Geçici ve Eşitsizlik alt temalarından oluşmaktadır. Avantaj ve Gerekli olarak adlandırılan 2 alt tema ise "olumlu" temasina aittir. 
"Olumsuz" temasının gerekçelerini oluşturan alt temalar incelendiğinde en çok görüş belirtilen alt temanın "aldatıcı" alt teması olduğu görülmektedir. Yine bu algıyı destekleyen benzer alt tema da "yapay" alt temasıdır. Öğrenciler, uzaktan eğitimin yüz yüze eğitimle karşılaştırmasını yaparak, uzaktan eğitimin yüz yüze eğitimin yerini tutmaya çalışan fakat ona benzemeye çalışsa da onun yerini tutamayan yapay öğrenme şekli olduğunu görüşüne sahiptirler. Özellikle pandemi döneminde yapılan uzaktan eğitimin, tam olarak onun yerine geçmiş bir uygulama olmadığı, kriz dönemine mahsus, öğrenme eksiklerini azaltma ve eğitiminin sürdürülmesini amaçlayan bir tedbir olduğu görüşü dile getirilmektedir (Karip, 2020). Dolayısılyla yüz yüze eğitim mantığı ile düşünen öğrencilerin, sanal eğitimde beklentilerinin karşılanamaması bu olumsuz düşüncenin oluşmasında etkili olmuş olabilir.

Öğrenciler, çoğunlukla "aldatıı" ve "yapay" olduğu algısına sahip oldukları uzaktan eğitimi, bu görüşlerinin bir uzantısı olarak "verimsiz" ve "etkisiz" olarak nitelendirmişlerdir. Akdemir ve Kılıç (2020) tarafından yapılan araştırmada yükseköğretim öğrencilerinden bazıları, uzaktan eğitimin yüz yüze verilen eğitim kadar etkili olmadığı ve herhangi bir verim alamadıkları gibi benzer düşünceler dile getirmiştir. Genç ve diğerleri (2021) tarafından yapılan araştırmada da "pandemi sürecinde online derslerde fakültede aldığım verimi alabiliyorum" ifadesine öğrencilerin sadece üçte biri katıldığını belirtmiştir. Ayrıca Genç ve Gümrükçüoğlu (2020) tarafından yapilan araştırmada online derslerden verim alabildiğini belirten öğrencilerin oranı \%15,3'te, öğretim elemanlarının sisteme yüklemiş olduğu ders materyallerinden yararlanabildiğini belirten öğrenci oranı $\% 28,3^{\prime}$ te, derslere konsantre olabildiğini belirtenlerin oranı \%17,8'de ve sinavlara konsantre olabildiğini belirten öğrenci oranı ise \%23,9'da kalmıştır. Öğrenciler uzaktan eğitimden yeterince verim alamadıklarını ifade ederek, okulda yüz yüze eğitimin önemini daha iyi kavradıklarını belirtmişlerdir (Genç - Gümrükçüoğlu, 2020). Yükseköğretim öğrencilerinin uzaktan öğretime karşı tutumlarına ilişkin bir araştırmada da bazı öğrenciler tarafından "uzaktan eğitimin olmasını kesinlikle istememe, bir artısının olmadığı düşünme" ve "kullanılan uygulamanın bir dersin işlenişini ne kadar değiştirilebileceğini sorgulama" gibi uzaktan eğitimin etkisiz olduğu yönünde benzer düşünceler dile getirilmiştir (Akdemir - Kılıç, 2020). Yaşadıkları çeşitli zorluklar ve yüz yüze eğitimle kıyaslama sonucunda bazı öğrencilerin, uzaktan eğitimin işlevselliğini sorguladıkları ve gereksizliğine inandıkları görülmektedir.

Yukarıdaki verilerden hareketle öğrencilerinin, uzaktan eğitimin pandemi döneminde eğitim ihtiyaçlarını karşılayan fakat yüz yüze eğitim kadar verimli olmayan bir uygulama olduğu görüşünde oldukları sonucu ortaya çıkmaktadır. Yüz yüze eğitim için planlanan öğrenme-öğretme süreçlerinin uzaktan eğitim için de kullanılmaya çalışılması, sürecin verimliliğini azaltmaktadır. Bütün hazırlıklarını yüz yüze eğitime göre planlamış, uzaktan eğitim konusunda tecrübesiz ve bu konuda bilgi ve beceri eksikleri olan ve hatta uzaktan eğitim konusunda olumsuz düşünceye sahip öğreticiler bulunmaktadır. Ayrıca öğrencilerin uzaktan eğitime katılım konusundaki teknik bilgi yetersizliği ve bulundukları yerlerdeki internet erişimi sorunları, öğren- 
cilerin verimlilik ile ilgili olumsuz düşünmelerinde etken olduğu söylenebilir. Dolay1sıyla uzaktan eğitimde öğrenme-öğretme süreçleri ve ölçme-değerlendirme etkinliklerinde yeni düzenlemelere ihtiyaç duyulmaktadır (Koç, 2021).

"Zorlayıcı" alt temasında öğrenciler, ders yükü yoğunluğu, evde ders çalışmanın zorluğu ve uzaktan eğitime ulaşım araçlarıyla ilgili sıkıntılardan dolayı uzaktan eğitimin zorluğunu ifade etmişlerdir. Bu zorlayıcı şartların sonucu olarak, uzaktan eğitim için gerekli olan araç-gereç ve bunların kullanım bilgisine sahip olma durumuna göre herkesin farklı düzeylerle yararlanabildiği "eşitsiz" bir durum ortaya çıkmaktadır. Yükseköğretim öğrencilerinin uzaktan eğitime bakışı ile ilgili bir araştırmada öğrenciler; daha çok emek gerektirme, bilgisayarın aile üyeleriyle paylaşılmasının öğrenciyi sınırlaması ve ödev yükünün çok arttığı gibi benzer zorlayıcı durumları dile getirmişlerdir (Akdemir - Kılıç, 2020) Ayrıca internet bağlantısı sorunu (Genç vd., 2021) ve çeşitli teknik aksaklıklar (Koç, 2020) gibi benzer sorunlar diğer araştırmalarda da dile getirilmiştir.

Eğitim kurumlarında yüz yüze eğitime ara verilmesinden sonra da devlet tarafından burs ve kredi ödemelerinin devam etmesi ve üniversitelerin, uzaktan eğitim sistemlerinin kullanımları ile ilgili kılavuzlar ve videolar yayınlayarak öğrencilere rehberlik yapmaları (Yavuz vd., 2020) uzaktan eğitime erişimdeki olumsuzlukları azaltmışır. Ancak öğrencilerin bulunduğu yerleşim birimlerindeki altyapı sorunları, internet kullanımındaki öğrenci yeterlikleri, uzaktan eğitime hazırlıksız yakalanmaları ve sokağa çıkma kısıtlamasından dolayı üniversitelerin kütüphane ve internet hizmetlerinden yararlanamamaları, düşük oranda da olsa öğrencilerde eşitsizlik algısının oluşmasında etkili olduğu düşünülebilir. Sınıf ortamında üniversitenin imkânlarından kolaylıkla eşit olarak yararlanan öğrenciler, uzaktan eğitimde kendi teknik imkânları, programları kullanım yeterlikleri ve yaşadıkları yerlerdeki sosyal şartlar ile başbaşa kalmanın zorluğu ve eşitsizliği ile karşı karşıya gelmişlerdir.

Uzaktan eğitimle ilgili, farklı bir olumsuz öğrenci algısı da uzaktan eğitimin yüz yüze iletişim ve sosyalleşme boyutundaki sorunları teşkil eden "uzaklık ve özlem" alt temasınında dile getirilmiştir. Öğrenciler, yüz yüze eğitimdeki öğrenme ortamına ve hocalarına olan özlemlerini dile getirerek, uzaktan eğitimin sosyalleşme imkânlarını sınırlandırıldığı düşüncelerinin ifade etmişlerdir. Bazı araştırmalarda da uzaktan eğitim uygulamasının, öğrencilerin sosyalleşmesini olumsuz etkilediği konusunda bu araştırma verilerini destekleyici benzer öğrenci görüşleri bulunmaktadır (Koç, 2020; Akdemir - Kılıç, 2020; Koç, 2021). Bu sebeple, öğrencilerin uzun süre evlerinde kapalı kalmalarından dolayı oluşan sosyal izolasyonun olumsuz etkilerini azaltmaya yönelik tedbirler alındığı ve öğrencilere rehberlik faaliyetleri düzenlendiği ifade edilmektedir (Karip, 2020; Yavuz vd., 2020; Sözen, 2020).

Bazı erkek öğrencilerin aile ekonomisine katkı için çalışmaya başladıkları, bazı kız öğrencilerin ise sanal dersler sırasında tarla ve ev işleri yapmak zorunda kaldıkları hatta okul ortamından uzaklaşmalarından dolayı evlililiğe zorlandıkları, araştırmacının uzaktan eğitim uygulamaları esnasında öğrencilerden aldığı dönütler arasındadır. Öğrenciler yüz yüze eğitimdeki olumlu sosyal ortamlardan uzak oldukları için 
bu konuda desteğe ihtiyaç duymaktadırlar. Dolayısıyla yüz yüze eğitiminin destekleyici sosyal ortamından izole bir durumu, uzaktan eğitim için bir olumsuzluk olarak nitelendirmektedirler. Bu görüşlerden yola çıkarak, öğrencilerin okul arkadaşları ve hocalarıyla etkileşimlerinin kısıtlanmasının, pandemi dönemindeki uzaktan eğitimin en belirgin sınırlılıklarından biri olduğu sonucuna ulaşılabilir.

Yukarıda sayılan olumsuzlukların sonucu olarak öğrenciler uzaktan eğitimi, niteliği tam olarak belli olmadığı için nereye savrulacağı bilinemeyen ve akıbeti hakkında endişelerinin olduğu "belirsiz" ve "geçici" bir durum olarak ifade etmişlerdir. Akdemir ve Kılıç (2020) tarafından yapılan araştırmada da öğrenciler uzaktan eğitimle ilgili belirsizliklerin, kendilerinde strese yol açtığı ile ilgili benzer görüşler dile getirmişlerdir. Bu süreçte pandeminin seyrine göre, öğrencileri her an yüz yüze eğitime çağırma kapısı açık tutulmaktadır. Bir yandan da öğrenci yurtlarının bir kısmı bulaş riski olan bazı vatandaşlar için geçiçi gözlem mekânlarına dönüştürülmüştür. Bu durum öğrencilerde hem öğretim uygulamaları hem de barınma imkânları konusunda bir belirsizliğe yol açmaktadır. YÖK'ün, oluşabilecek belirsizliği gidermeye yönelik, süreçle ilgili sürekli bilgilendirme yapması endişeleri büyük ölçüde gidermesine rağmen, pandeminin seyrine göre yüz yüze eğitim kapısının sürekli açık tutulmasının az da olsa belirsizliği yol açtığı görülmektedir.

Olumsuz teması altında toplanan dokuz alt tema incelendiğinde, sorunların daha çok uzaktan eğitime erişimle ilgili teknik imkânsızlıklar, herkesin bu konuda eşit olmadığı ve eğitim gördükleri şehirden ailelerinin yanına dönen öğrencilerin yaşadıkları olumsuz sosyal şartlar öne çıkmaktadır. Bundan dolayı olsa gerek, eğitim süreçleri ile ilgili görüşler yukarıda sayılan sorunların gölgesinde kalmıştır. Öğretim yöntemleri, araç-gereç kullanımı, sınıf yönetimi, ölçme ve değerlendirme konularında olumlu veya olumsuz anlamda öğrenci görüssleri sayı olarak çok alt düzeyde kalmıştır. Öğretim süreçleriyle ilgili görüşlerin ikinci planda kalması, daha önce bu konuda tecrübe yaşanmaması ve bu araştırmanın, uygulamanın ilk yılında yapılmasından kaynaklandığı değerlendirilebilir.

Yükseköğretim öğrencilerinin uzaktan eğitimle ilgili görüşleri bağlamında oluşturulan ikinci tema "olumlu" temasıdır. Uzaktan eğitim konusunda olumlu düşünen öğrenciler hem evde olmanın konforunu hem de öğrenime devam etmenin "avantaj"ını yaşadıklarını dile getirmiştir. Konuyla ilgili araştırmalarda öğrenciler; "ev konforunda dersi sevme" "okula gitmemenin tatlı gelmesi"(Akdemir - Kılıç, 2020) "vakit tasarrufu, derslere kolay ulaşma ve dersin tekrarını dinleme" (Genç vd., 2021) "kendilerini daha rahat hissetmeleri", "zamandan tasarruf sağlaması" (Koç, 2020) gibi uzaktan eğitimin sağladığı avantajlarla ilgili benzer düşünceler dile getirmiştir. Yaşanan olumsuzluklara rağmen, pandemi dönemindeki uzaktan eğitim uygulaması, bazı fırsatları da beraberinde getirmiştir. Gelişmiş üniversitelerin YÖK Anadolu Projesi bağlamında uzaktan eğitim yoluyla, genç üniversitelere ders verecek öğretim üyesi desteği sağlaması, bu dönemin en önemli avantajlarından biri olarak değerlendirilebilir. ${ }^{6}$ Ayrıca

6 https://www.yok.gov.tr/Documents/Yayinlar/Yayinlarimiz/2021/anadolu-projesi-brosur.pdf Erişim, 08/05/2021 
ilahiyat alanı ile ilgili bazı derslerin online öğretim yöntemleri ile nasıl yapılabileceği konusunda çalışmaların başlaması da (Başkonak - Akşener, 2020) uzaktan eğitim sürecinin alana katkılarındandır.

Uzaktan eğitimin olumlu olarak değerlendirilmesinde ikinci etken uzaktan eğitimin, pandemi sürecinde yüz yüze eğitimin yerini doldurması ve eğitimde kesinti yaşanmaması için bir "gereklilik" olarak görülmesidir. Öğreticilerin, öğrencilerin ve eğitim kurumlarının hazırlıksız yakalandıkları pandemi sürecinde, uzaktan eğitim faaliyetleri herkes için bir tercih değil zorunluluktur. Uzaktan eğitimde sorun yaşayan öğrencilere YÖK tarafından kayıt dondurma hakkı tanınsa da pandemi sürecinin ne kadar devam edeceği ile ilgili belirsizlik, yıl kaybı, arkadaşlarından geri kalma gibi sebepler bu seçeneği devre dışı bırakmaktadır. Dolayısıyla bu süreci en az kayıpla atlatmak isteyen eğitim kurumları, öğreticiler ve öğrenciler için, iyileştirme çabaları devam eden uzaktan eğitim, alternatifsiz bir gereklilik olarak bulunmaktadır. Ayrıca bu süreçte uygulanan uzaktan eğitim faaliyetlerinin, yüz yüze eğitime geçildikten sonra bazı derslerin online yapılması, işlenemeyen derslerin telafisi vb. konularda iyi bir tecrübe ve alternatif olduğu söylenebilir. Nitekim YÖK’ün, pandemi sonrası da bazı derslerin uzaktan eğitim yoluyla yapılabileceği ile ilgili kararları da vardır. Ancak öğrencilerden alınan dönütler de dikkate alınarak niteliğinin geliştirilmesine ihtiyaç bulunmaktadır.

Olumlu ve olumsuz teması ile ilgili bütün görüşler değerlendirildiğinde öğrencilerin pandemi sürecindeki uzaktan eğitim konusunda çoğunlukla $(164 / \% 83,2)$ olumsuz düşündükleri sonucu ortaya çıkmaktadır. Genç ve Gümrükçüoğlu (2020) tarafından yapılan araştırma sonuçları da İlahiyat Fakültesi öğrencilerinin bu konudaki görüşlerinin çoğunlukla olumsuz olduğu yönündedir. Bu araştırmaya konu edilen uzaktan eğitim, üniversitelerin; öğretim tasarımı ve içerik düzenleme, ekran tasarımı ve teknik kapasite yönüyle planlanmış, altyapısı oluşturulmuş (Gülnar, 2008) İLiTAM, vb. uzaktan eğitim programları değildir. Bilakis pandemi süreci şartlarında, hazırlıksız yakalanılmış, bazı zamanlar öğrencilerin dışarı çıkmalarının bile kısıtlı olduğu, ne kadar devam edeceği net olarak belli olmayan, geçici bir süreyle uygulamaya konulmuş bir eğitim faaliyetidir. Doğal olarak bazı belirsizlik, kaygı ve zorlukları beraberinde getirmesi kaçınılmazdır.

İlahiyat alanında lisansüstü eğitim öğrencilerinin uzaktan eğitimle ilgili görüşlerini belirlemeye yönelik yapılan bir araştırmada (Genç vd., 2021) bu araştırmadan farklı bir sonuç ortaya çıkmış ve lisansüstü eğitim öğrencileri uzaktan öğretimle ilgili genel olarak olumlu görüşler beyan etmişlerdir. Ancak ilgili araştırma lisans öğrencileri ile değil, lisansüstü eğitim öğrencileri ile yapılmıştır. Sonucun olumlu çıkması da araştırmacıların ifadesiyle; olumsuzlukları aşma noktasındaki gayretleri öğrencilerin lisansüstü eğitim tercihinde bilinçli olmalarına ve tez döneminde olan bazı öğrencilerin enstitülerinden farklı şehirde bulunmaları ve danışman hocaları ile zaten uzaktan iletişim kurmalarına bağlanmaktadır (Genç vd., 2021).

Yükseköğretim kurumlarında uzaktan öğretime ilişkin usul ve esaslar, Madde 6. 
Uzaktan eğitimle ilgili olarak oluşturulan "olumlu" ve "olumsuz" temalarının cinsiyete göre dağılım verileri benzer çıkmıştır. Öğrencilerin sınıf düzeyleri ile ilgili veriler incelendiğinde 2. sınıf öğrencilerinin diğer sınıflara göre biraz daha fazla olumsuz metaforlar ürettikleri görülmüştür. Bu konuda 1. sınıf veya 4. sınıf öğrencilerinin değil de ara sınıf olan 2. sınıfların daha fazla olumsuz düşünmeleri ilginçtir. Metafor örnekleri gerekçeleriyle birlikte incelendiğinde diğer sinfflardan farklı olarak, sadece 2. sınıflara mahsus olumsuz bir gerekçelendirmeye rastlanmamıştır. Öğrencilerin uzaktan eğitime katıldıkları yerleşim birimine göre üretilen metaforların dağılımları incelendiğinde ise, köydeki internet erişimi ve uzaktan eğitim araçlarının sınırlılıkları düşünüldüğünde beklenenin aksine köyden katılanların diğer yerleşim yerlerinden katılanlara göre daha fazla olumlu görüş belirttikleri tespit edilmiştir. Bu verilerden hareketle öğrencilerin bulundukları yerleşim yerlerinde uzaktan eğitime ulaşım konusunda kayda değer sorunlar yaşanmadığı sonucuna ulaşlabilir.

Pandemi sürecinde sorun yaşayan öğrencilere YÖK tarafından kayıt dondurma hakkı tanınmış ve bunun azami öğretim sürecinden sayılmayacağı belirtilmiştir. Öğrencilerin uzaktan eğitimle ilgili ürettikleri metaforlar çoğunlukla olumsuz olmasına rağmen, katılımcı öğrencilerin eğitim aldığı İslami İlimler Fakültesinde hiçbir öğrencinin pandemi sürecinde kayıt dondurma yolunu tercih etmedikleri bilakis kayıt donduran bazı öğrencilerin uzaktan eğitim imkânından yararlanmak için kayıt yeniledikleri bilgisi alınmıştır. Benzer şekilde Genç ve diğerleri (2021) tarafından yapılan araştırma bulgularına göre, pandemi sürecinde lisansüstü eğitim öğrencilerinden çoğunluğu kaydını dondurmayı düşünmediğini belirtmiştir. Bütün bu veriler, pandemi sürecinin başında ortaya çıkan bazı olumsuzlukların zamanla aşıldığı ve öğrencilerin yukarıda sayılan olumsuzluklara rağmen zorunlu uzaktan eğitime uyum sağlamaya başladıkları anlamında değerlendirilebilir. Ancak bu sürdürülebilir bir durum değildir. Zira mevcut durumda öğrenci, öğretici ve teknik altyapı uzaktan eğitime göre oluşturulmamıştır. Pandemiden kaynaklı çeşitli imkânsızlıklara karşı öğrencilere bazı konularda tolerans gösterilmiştir. Öğretim süreçleri, derslere öğrenci katılımı ölçme ve değerlendirme konularındaki belirsizlikler beraberinde bazı endişeler oluşturmaktadır. Sanal ortamda uygulamalı derslerin yapılmasındaki imkânsızlıklar ve bu konudaki öğrenme eksiklerin telafisinin zorluğu, öğrenci yeterliklerini olumsuz etkileyecektir. Netice olarak, uzaktan eğitim uygulamalarından kaynaklanan sorunların yüz yüze eğitime geçildikten sonra daha belirgin olarak gözlemleneceği söylenebilir. Pandemi sonrası, durum tespiti yapmak ve öğrenme eksiklerinin telafisi için üniversitelerin iyi bir planlamaya ihtiyacı bulunmaktadır.

\section{2. Öneriler}

Çalışmanın sonuçlarına dayalı olarak uzaktan eğitim uygulamaları için aşağıdaki öneriler getirilebilir:

- Öğrencilerin çoğunluğu uzaktan eğitim uygulamalarını yüz yüze eğitimin yerini tutmayan yapay, etkisiz ve verimsiz bir uygulama olduğu görüşündedirler. Bu olum- 
suzlukları gidermeye yönelik; uzaktan eğitim konusunda yapılan araştırma verileri ve fakülteler özelinde öğrenci ve öğretici görüşleri dikkate alınarak, sorunlu konularda iyileştirme çalışmaları yapılabilir. Bu bağlamda; uzaktan eğitimde içerik oluşturma, öğretim yöntemleri, sınav oluşturma ve uygulama gibi konularda öğreticilerin yeterliklerini artırmaya yönelik hizmet içi eğitim faaliyetleri ve tecrübe paylaşım toplantıları gerçekleştirilebilir. Uzaktan eğitim süreci ile ilgili görseller hazırlanıp öğrencilere ulaştırılabilir. Öğrencilerin derslere aktif katılımını sağlama yönelik motivasyon araçları geliştirilebilir.

- Öğrencilerin hocalarına ve okul arkadaşlarına özlemlerini dile getirdikleri görülmüştür. Uzun süre evde kalmanın etkilerini ve yüz yüze eğitimdeki öğrenme ortamlarındaki sosyalleşme özlemlerini gidermek için online, ders dışı sohbetler ve farklı etkinlikler düzenlenebilir. Üniversitelerdeki rehberlik birimleri daha etkin hale getirilerek, öğrencilere bu birimlerden yararlanabilecekleri konusunda duyurular yapilabilir.

- Öğrenciler sürecin geçici olduğu ve her an yüz yüze eğitime geçilebileceği konusunda endişe ve belirsizlik içinde olduklarını dile getirmişlerdir. Bu belirsizliklerin aşılması için, eğitime nasıl devam edileceği ile ilgili kararlarının dönemlik alınması, ders işleniş yöntemleri, sınav tarihleri ve uygulama şekillerinin dönem başında belirlenerek öğrencilere bildirilmesi uygun olacaktır.

\section{Kaynakça}

Akdemir, Ayşe Betül - Kllı̧, Abdurrahman. "Yükseköğretim Öğrencilerinin Uzaktan Eğitim Uygulamalarına Bakışı”. Milli Eğitim Dergisi 49/Salgın Sürecinde Türkiye'de ve Dünyada Eğitim (2020), 685-712. https://doi.org/DOI: 10.37669/milliegitim.783344

Aristoteles. Retorik. çev. Mehmet H. Doğan. İstanbul: Yapı Kredi Yayınları, 1995.

Arslan, M. Metin - Bayrakcı, Mustafa. "Metaforik Düşünme ve Öğrenme Yaklaşımının Eğitim-

Öğretim Açısından İncelenmesi”. Milli Eğitim Dergisi 171 (2006), 100-108.

Aydın, Fatih. “Üniversite Öğrencilerinin 'Çevre' Kavramına İlişkin Metaforik Algıları”. Doğu Coğrafya Dergisi 16/26 (2013), 25-44.

Baltac1, Ali. "Veri Analizinde Miles-Huberman Modeli". Ahi Evran Üniversitesi Sosyal Bilimler Enstitüsü Dergisi 3/1 (2017), 1-15.

Başkonak, Mustafa - Akşener, Ayşe. "Kuran Öğretiminde Yeni Yaklaşımlar: On Saatte Online

Kuran Eğitimi Örneği”". Şırnak Üniversitesi Illahiyat Fakültesi Dergisi 11/25 (2020), 714-740. https://doi.org/10.35415/sirnakifd.786941

Cabı, Emine - Ersoy, Halil. "Yükseköğretimde Uzaktan Eğitim Uygulamalarının İncelenmesi:

Türkiye Örneği”. Yükseköğretim ve Bilim Dergisi 7/3 (2017), 419-429.

Cevizci, Ahmet. Felsefe Sözliügü. İstanbul: Paradigma, 3. Basım, 1999.

Çelik, Hilal vd. "Nitel Veri Analizi ve Temel İlkeleri". Eğitimde Nitel Araștrmalar Dergisi 8/1 (2020), 379-406.

Demir, Ömer. "Öğretmen Adaylarını Metaforik Çevre Algıları". International Journal of Social Sciences and Education Research 3/5 (2017), 1700-174.

Diler, Ramazan. Gazetelerde Din Dersi Tartışmaları. Ankara: İlahiyat, 1. Basım, 2020.

Gencer, Muharrem. "Öğrenci ve Velilerin Öğretmen Kavramına İlişkin Metaforik Algıları". Balkesir Üniversitesi Sosyal Bilimler Enstitüsü Dergisi 23/44 (2020), 805-825. 
https://doi.org/10.31795/baunsobed.742089

Genç, Muhammet Fatih vd. "Koronavirüs (Covid-19) Sürecinde İlahiyat Alanında Lisansüstü Eğitim Gören Öğrencilerin Uzaktan Eğitime Bakışları”. Dinbilimleri Akademik Araştırma Dergisi 21/1 (2021), 71-97. https://doi.org/10.33415/daad.840675

Genç, Muhammet Fatih - Gümrükçüoğlu, Süleyman. "Koronavirüs (Covid-19) Sürecinde İlâhiyat Fakültesi Öğrencilerinin Uzaktan Eğitime Bakışları". Turkish Studies 15/4 (2020), 403422.

https://dx.doi.org/10.7827/TurkishStudies.43798

Gülnar, Birol. "Bilgisayar ve İnternet Destekli Uzaktan Eğitim Programlarının Tasarım, Geliştirme ve Değerlendirme Aşamaları (Suzep Örneği)”. Selçuk Üniversitesi Sosyal Bilimler Enstitüsü Dergisi 19 (2008), 259-271.

Gürbüzoğlu Yalmancı, Sibel - Aydın, Solmaz. "Öğretmen Adaylarının Kopya Çekmeye Yönelik Metaforik Algıları”. Erzincan Üniversitesi Eğitim Fakültesi Dergisi 16/1 (2014), 316-332.

İşman, Aytekin. Uzaktan Eğitim. Ankara: Pegem Akademi, 3. Basım, 2008.

Karateke, Tuncay. "İmam Hatip Lisesi Öğrencilerinin İmam Hatip Lisesi, Meslek Dersi Öğretmeni ve İdarecilerine İlişkin Metaforik Algıları". Cumhuriyet İlahiyat Dergisi 23/3 (2019), 1235-1256. https://doi.org/10.18505/cuid.620035

Karip, Emin. “COVID-19: Okulların Kapatılması ve Sonrası”, 2020. Erişim 07 Mayıs 2021. https://tedmem.org/vurus/covid-19-okullarin-kapatilmasi-ve-sonrasi

Koç, Ahmet. “Covid-19 Salgını Sürecinde İlahiyat Fakültesi Öğretmenlik Uygulaması Dersinin Uzaktan Eğitim Yoluyla Yapılması: Örnek Bir Uygulama Modeli”. Milli Eğitim Dergisi 49/Salgın Sürecinde Türkiye'de ve Dünyada Eğitim (2020), 851-875. https://doi.org/10.37669/milliegitim.770561

Koç, E. Seda. "Nasıl Bir Uzaktan Eğitim? 1 Yılın Sonunda Yapılan Çalışmaların Değerlendirilmesi”. Sosyal Bilimler Dergisi 7/2 (2021), 13-27.

Meydan, Hasan. "Kampüste İlahiyat Eğitiminin Avantaj ve Meydan Okumaları: Öğrenci Görüşlerine Dayalı Metaforik Bir Araştırma”. Cumhuriyet İlahiyat Dergisi 24/1 (2020), 47-71. https://doi.org/10.18505/cuid.668833

Özdemir, Şuayip - Karateke, Tuncay. “Yaz Kur’an Kursu Öğrencilerinin 'Cami’ ve ‘Din Görevlisi' Kavramlarına İlişkin Metaforları”. Uluslararası Cami Sempozyumu (Sosyo-Kültürel Açıdan) 0809 Ekim 2018 Malatya, 2018.

Polatcan, Mehmet - Kılıç, Ali Çağatay. "Fenomenoloji ve Araştırmalarda Fenomenolojik Yöntem”. Eğitim Yönetiminde Araştırma. ed. Kadir Beycioğlu, Niyazi Özer, Yaşar Kondakçı. 391408. Ankara: Pegem Akademi, 1. Basım, 2018.

Saban, Ahmet. "ilköğretim I. Kademe Öğretmen ve Öğrencilerinin Bilgi Kavramına İlişkin Sahip Oldukları Zihinsel İmgeler”. İlköğretim Online 7/2 (2008), 421-455.

Selçuk, Mualla vd. "The Online Learning Experience of Theology Students in Turkey During The Covid-19 Pandemic: A New Disposition For RE?". Religious Education 116/1 (2021), 74-90.

Sözen, Nurhüda. "Covid 19 Sürecinde Uzaktan Eğitim Uygulamaları Üzerine Bir İnceleme". Avrasya Sosyal ve Ekonomi Araştırmaları Dergisi 7/12 (2020), 302-319.

Şimşek, Hasan - Yıldırım, Ali. Sosyal Bilimlerde Nitel Araştırma Yöntemleri. Ankara: Seçkin Yayıncılık, 9. Basım, 2013.

Taş, Halil. "İlkokul Öğrencilerinin Din Kültürü ve Ahlak Bilgisi Dersi ile Din Kültürü ve Ahlak Bilgisi Öğretmenine İlişkin Metaforları”. Cumhuriyet İlahiyat Dergisi 23/1 (2019), 29-51. https://doi.org/10.18505/cuid.518013 
Tuncay, Nazime - Özçınar, Zehra. “Distance Education Students' ‘Metaphors”'. Procedia Social and Behavioral Sciences 1/1 (2009), 2883-2888.

Turan, Mehmet vd. “Öğretmen Adaylarının Eğitim ve Bazı Temel Kavramlara İlişkin Metaforik Algiları". Education Sciences 11/4 (2016), 217-242.

Yavuz, Mehmet vd. “Salgın Sürecinde Türkiye'deki Yükseköğretim Kurumlarının Acil Uzaktan Öğretim Uygulamalarının İncelenmesi”. Milli Eğitim Dergisi 49/Salgın Sürecinde Türkiye'de ve Dünyada Eğitim (2020), 129-154.

Yıldırım, Ramazan - Gazel, Mehmet Ali. “Ortaokul Öğrencilerinin Din Kavramına İlişkin Algılarının Metaforlar Aracılı̆̆ıyla Belirlenmesi”. Kuramsal Eğitimbilim Dergisi 11/1 (2018), 30-57. 